\title{
Dynamics of reserves of soybean seeds during the development of seedlings of different commercial cultivars ${ }^{1}$
}

\author{
Welison Andrade Pereira ${ }^{2 *}$, Sara Maria Andrade Pereira ${ }^{3}$, \\ Denise Cunha Fernandes dos Santos Dias ${ }^{4}$
}

\begin{abstract}
Physiological quality and vigor of the seeds comprise properties that determine a high level of activity and performance during germination and seedling emergence, having a direct relation with the establishment of the stand of a crop. In this context, the assessment of seedling development, including the analysis of the seed reserves mobilization are a reliable method to investigate the physiological potential of seed lots. In this preliminary study, the aim was to investigate the dynamics of seed reserves mobilization of a sample of soybean commercial cultivars. By means of the seedling length bioassay and weight of dry matter of seeds, cotyledons, hypocotyls and radicles, information on the reserves mobilization during the germination process was obtained. Data were subjected to analysis of variance and Scott and Knott test, and afterwards, phenotypic correlations between traits were obtained. The results have shown that the dry matter of seeds, reserves reduction of seeds and dry matter of seedlings are positively correlated, and thus, seeds containing more reserves may be more effective during the early development of seedlings. In contrast, reserve reduction of seeds and conversion efficiency of the seeds reserves in the dry matter of seedlings are negatively correlated.
\end{abstract}

Index terms: Glycine $\max ($ L.) Merrill, germination, seedlings, reserves mobilization.

\section{Dinâmica de reservas das sementes de soja durante o desenvolvimento de plântulas de diferentes cultivares comerciais}

\begin{abstract}
RESUMO - Qualidade fisiológica e vigor compreendem propriedades das sementes que determinam alto nível de atividade e desempenho durante a germinação e emergência das plântulas, tendo relação direta com o estabelecimento do estande de uma lavoura. Neste contexto, a avaliação do desenvolvimento das plântulas, incluindo análise da mobilização de reservas das sementes pode se constituir em um método confiável para investigação do potencial fisiológico de lotes. Neste estudo preliminar, objetivou-se investigar a dinâmica de reservas em sementes de cultivares comerciais de soja. Por meio do teste de comprimento de plântulas e peso de massa seca de sementes, cotilédones, hipocótilos e radículas foram obtidas informações sobre a mobilização de reservas durante o processo de germinação. A massa seca de sementes, redução de reservas de sementes e massa seca de plântulas estão positivamente correlacionados entre si, e, logo, sementes contendo mais reservas podem apresentar maior vigor durante o desenvolvimento inicial de plântulas. Em contrapartida, redução de reserva de sementes e eficiência na conversão de reservas das sementes em massa seca de plântulas são negativamente correlacionadas.
\end{abstract}

Termos para indexação: Glycine $\max ($ L.) Merrill, germinação, plântulas, mobilização de reservas.

\section{Introduction}

Vigor is a set of properties that contribute to indicate the quality of seeds, relating them to the potential for germination, seedling emergence and storage capacity under conditions different from those considered standard (Sun et al., 2007).

${ }^{1}$ Submitted on 10/29/2014. Accepted for publication on 3/17/2015.

${ }^{2}$ Departamento de Biologia, UFLA, Caixa Postal 3037, 37200-000, Lavras, MG, Brasil.

${ }^{3}$ Departamento de Produção Vegetal, UFES, Caixa Postal 16, 29500-000 Alegre, ES, Brasil.
Seeds with high vigor give rise to seedlings which emerge quickly, uniformly and completely from the ground (Soltani et al., 2006), which gives them a competitive advantage over weeds (Dias et al., 2011).

The establishment of the stand of a crop is related to seed vigor because seedlings grown from seeds with reduced

${ }^{4}$ Departamento de Fitotecnia, UFV, 36570-000 - Viçosa, MG, Brasil.
*Corresponding author < welison.pereira.ufv@gmail.com> 
vigor slowly emerge from the soil, are smaller in height and dry matter accumulation (Henning et al., 2010), later as to flowering, and form a lower final population in the field (Vanzolini and Carvalho, 2002). With regard to plant height, lower insertion of the first pod results in lower yield (Câmara et al., 1998). Regarding the faults at the stand, a number of negative implications for crop is triggered, such as the loss in competitiveness with weeds (Dias et al., 2011); lower shading of the soil, thus more evaporation, and thus less available water for the crop; low interception to the light and interruption in the yield potential (Nepomuceno et al., 2007; Valério et al., 2009) and little growth in early seasons (Carvalho et al., 2008).

Given the due importance to seed physiological quality and seedling vigor, the assessment of hypocotyls, radicle and seedling (Vanzolini et al., 2007), as well as the analysis of seed reserves content (Henning et al., 2010), are reliable methods for assessment of the physiological potential of the seeds. Based on the literature, seed lots with high quality and vigor have higher seedling and are able to accumulate more dry matter (Schuab et al., 2002; Henning et al., 2010), and, in general, larger seeds have a better physiological quality (Pereira et al., 2013). These findings may be related to the fact that high vigor seeds have a higher starch content, soluble proteins and sugars, and also greater capacity to mobilize reserves during the germination period (Henning et al., 2010).

The dry matter content of the seedlings can be determined in addition to the test of seedlings length (Pereira et al., 2009), and the reduction of reserves of cotyledons and the conversion efficiency of these reserves into dry matter in the seedlings may also be studied (Soltani et al., 2006).

The dynamics of reserves is noteworthy because it represents a fundamental part of the germination process. First, the embryo starts this process with its own reserves, but maintaining it will depend on a flow of soluble components of its reserves for the regions in full development (Henning et al., 2010). Thus, when the genetic variability for such characters is found, these can be considered in enhancement programs, with the goal of searching for genotypes with greater potential to mobilize and convert reserves contained in the cotyledons in the dry matter of seedlings.

Given the above, the objective was to work with the preliminary information on the dynamics of reserves of soybean seeds commercial cultivars, in order to extend a posteriori such methodology for the assessment of strains obtained in a soybean enhancement program at Universidade Federal de Viçosa. Thus, this study aimed to analyze the mobilization of reserves during the process of germination of seedlings of different soybean cultivars and the existence of correlations between the characteristics studied.

\section{Material and Methods}

All assays were conducted in Soybean Genetics Laboratory at Department of Plant Science at Universidade Federal de Viçosa, Viçosa, MG, Brasil). Characteristics were assessed that could show the dynamics of reserves of seeds of 14 soybean cultivars, Glycine $\max$ (L.) Merrill: CD202, CD206, CD211, CD217, CD219, UFV16, UFV18, UFV19, UFVTN103, UFVTN105, MONARKA, MSOY8605, CONFIANÇA and EMGOPA315.

The seeds used in this study were multiplied in the harvest immediately preceding the experiments, allowing that all tests could be performed with freshly harvested seeds, as performed by Soltani et al. (2006).

To obtain the water content (WC), three replications of 50 seeds were weighed (W1), taken to an oven at a temperature of $105{ }^{\circ} \mathrm{C}$ for 24 hours and reweighed (W2). In this procedure, in addition to water content, based on the equation $T A=\frac{W 1-W 2}{W 1}$, the dry matter of seeds was also obtained (DWS), W2 (Soltani et al., 2006), understood, for the purposes of this study, as the total reserve of seeds available to be mobilized to the seedlings.

The germination test (GR) was conducted with four replications of 50 seeds, distributed in paper towel moistened with distilled water at a ratio of 2.5 times the weight of the dry paper (Brasil, 2009), making up rolls which were maintained in a germination chamber (B.O.D. (Biochemical Oxygen Demand)) under controlled temperature $\left(25 \pm 1^{\circ} \mathrm{C}\right)$ for 7 days. At the end of that period, the number of normal seedlings was counted.

The seedling length test was conducted with four replications of 20 seeds placed in the upper third of the paper towel (Pereira et al., 2009), with their micropyles directed to the base (Vanzolini et al., 2007). Seven days after seeding, hypocotyls, radicles and seedlings were measured in centimeters. Obtaining the average length of hypocotyl, radicle and seedling of the plot followed two recommendations: ISTA (International Seed Testing Association), the sum of the lengths of the seedlings divided by the number of seeds put to germinate; and AOSA (Association of Official Seed Analysts, 2009), the sum of the lengths divided by the number of seedlings measured, according to Vanzolini et al. (2007). Thus, mean lengths were obtained for radicle (RRL and ARL), hypocotyl (RHL and AHL) and seedling (RLS and ALS), according to recommendations from ISTA and AOSA, respectively.

Once the length measures were taken, the hypocotylradicle axes were separated from the cotyledons and taken to the oven at a temperature of $80 \pm 1{ }^{\circ} \mathrm{C}$ for 24 hours. After this period, the material was weighed, giving rise to the dry matter of the experimental plot (SDMW). This value (SDMW) was divided by the number of seedlings placed to dry, resulting in dry matter weight per individual. Due to the 
need to sequentially analyze how much dry matter of the 50 seeds was mobilized to the seedlings of each plot, the value found by individual was multiplied by 50 , thus estimating an approximate value for 50 seedlings (EDMW - Estimated Dry Matter Weight for 50 seedlings), if the germination had been $100 \%$. For the remaining dry matter of the cotyledons (RDWC), the pairs of cotyledons reserved during the length measurement procedure of the seedlings were placed to dry in an oven at $80 \pm 1{ }^{\circ} \mathrm{C}$ for 24 hours and then weighed. In order to match all weights, these values were also estimated for 50 pairs of cotyledons, a procedure adapted from the methodologies presented by Soltani et al. (2002) and Soltani et al. (2006).

From the dry matter remaining from the cotyledon (RDWC) and the dry matter weight of the seeds (DWS) it was possible to obtain the seeds reserve reduction value (RRS) by the formula: $R R S=D W S-R D W C$. As soon as the values of the seeds reserve reduction and the seed estimated dry matter weight for 50 seedlings (EDMW) were obtained, the value corresponding to the conversion efficiency of the reserves in seedling dry matter was obtained (CESR) from the equation: $E C R=E D M W / R R S$. This value allowed for estimating the proportion of the reduced dry matter of the seeds turned into seedling dry matter. As for the relative yield of dry matter (RYDM), it was obtained from the ratio between the weight of the experimental unit (SDMW) and the number of seeds placed in the test (20). The higher the value the higher the dry matter yield and/or number of developed seedlings. Finally, the seed reserve reduction rate (SRRR) obtained by the equation $S R R R=R R S / D W S$ has allowed for the identification of the genotypes that most mobilized dry matter (Soltani et al., 2006).

Initially, the data were subjected to analysis of variance and Scott-Knott mean test at 5\% probability. Then the phenotypic correlations were obtained between the characteristics assessed.

\section{Results and Discussion}

Differences were found among the genotypes by the $\mathrm{F}$ test at 5\% probability for all the studied traits.

The minimum value for water content was $10.3 \%$ and the maximum $11.6 \%$. As for germination, it is observed in Table 1 that the genotypes obtained different germination percentages. Physiological quality and vigor relate to normal seedling development (Dias et al., 2011; Vanzolini et al., 2007), therefore the presence of different lots was important for the interpretation of the results in this regard.

Table 1. Means of 16 characteristics of 14 soybean genotypes and formation of groups by the Scott-Knott criterion.

\begin{tabular}{|c|c|c|c|c|c|c|c|c|}
\hline \multirow{3}{*}{ Cultivars } & \multicolumn{8}{|c|}{ Assessed characteristics $/ 1$} \\
\hline & $\mathrm{WC}^{/ 2}$ & $\mathrm{GR}^{/ 3}$ & $\mathrm{RRL}^{/ 4}$ & $\mathrm{ARL}^{15}$ & $\mathrm{RHL}^{/ 6}$ & $\mathrm{AHL}^{17}$ & $\mathrm{RLS}^{/ 8}$ & $\mathrm{ALS}^{/ 9}$ \\
\hline & $\%$ & $\%$ & $\mathrm{~cm}$ & $\mathrm{~cm}$ & $\mathrm{~cm}$ & $\mathrm{Cm}$ & $\mathrm{cm}$ & $\mathrm{cm}$ \\
\hline CD211 & $10.18 \mathrm{f}$ & $82.5 \mathrm{~b}$ & $18.33 \mathrm{a}$ & 22.22 & $8.77 \mathrm{~b}$ & $10.58 \mathrm{c}$ & $27.10 \mathrm{~b}$ & $32.80 \mathrm{~b}$ \\
\hline CD219 & $10.24 \mathrm{f}$ & $83.7 \mathrm{~b}$ & $17.80 \mathrm{~b}$ & 21.22 & $8.98 \mathrm{~b}$ & $10.74 \mathrm{c}$ & $26.79 \mathrm{~b}$ & $31.97 \mathrm{~b}$ \\
\hline Emgopa315 & $10.82 \mathrm{~d}$ & $92.5 \mathrm{a}$ & $19.37 \mathrm{a}$ & 21.22 & $11.66 \mathrm{a}$ & $12.77 \mathrm{~b}$ & $31.03 \mathrm{a}$ & $34.00 \mathrm{a}$ \\
\hline UFV19 & $11.19 \mathrm{~b}$ & $88.7 \mathrm{a}$ & $18.66 \mathrm{a}$ & 21.12 & $10.74 \mathrm{a}$ & $12.20 \mathrm{~b}$ & $29.41 \mathrm{a}$ & $33.31 \mathrm{a}$ \\
\hline CD202 & $11.13 \mathrm{~b}$ & $51.2 \mathrm{~d}$ & $11.14 \mathrm{~d}$ & 21.75 & $5.42 \mathrm{c}$ & $10.62 \mathrm{c}$ & $16.56 \mathrm{~d}$ & $32.36 \mathrm{~b}$ \\
\hline UFVTN103 & $11.03 \mathrm{c}$ & $83.7 \mathrm{~b}$ & $17.75 \mathrm{~b}$ & 21.21 & $9.77 \mathrm{~b}$ & $11.66 \mathrm{c}$ & $27.51 \mathrm{~b}$ & $32.87 \mathrm{~b}$ \\
\hline UFV18 & $10.88 \mathrm{~d}$ & $80.0 \mathrm{~b}$ & $16.10 \mathrm{~b}$ & 20.08 & $8.94 \mathrm{~b}$ & $11.16 \mathrm{c}$ & $25.04 \mathrm{~b}$ & $31.24 \mathrm{~b}$ \\
\hline UFV16 & $10.93 \mathrm{c}$ & $70.0 \mathrm{c}$ & $14.46 \mathrm{c}$ & 20.65 & $8.37 \mathrm{~b}$ & $12.01 \mathrm{~b}$ & $22.83 \mathrm{c}$ & $32.66 \mathrm{~b}$ \\
\hline MSOY8605 & $10.55 \mathrm{e}$ & $90.0 \mathrm{a}$ & $19.02 \mathrm{a}$ & 21.15 & $11.52 \mathrm{a}$ & $12.83 \mathrm{~b}$ & $30.54 \mathrm{a}$ & $33.98 \mathrm{a}$ \\
\hline Confiança & $10.83 \mathrm{~d}$ & $88.7 \mathrm{a}$ & $19.21 \mathrm{a}$ & 21.67 & $11.17 \mathrm{a}$ & $12.57 \mathrm{~b}$ & $30.38 \mathrm{a}$ & $34.23 \mathrm{a}$ \\
\hline UFVTN105 & $11.15 \mathrm{~b}$ & $81.2 \mathrm{~b}$ & $16.67 \mathrm{~b}$ & 20.51 & $9.08 \mathrm{~b}$ & $11.20 \mathrm{c}$ & $25.75 \mathrm{~b}$ & $31.71 \mathrm{~b}$ \\
\hline CD 206 & $10.30 \mathrm{f}$ & $91.2 \mathrm{a}$ & $19.52 \mathrm{a}$ & 21.37 & $12.80 \mathrm{a}$ & $14.02 \mathrm{a}$ & $32.32 \mathrm{a}$ & $35.40 \mathrm{a}$ \\
\hline Mean & 10.83 & 82.5 & 17.44 & 21.16 & 9.90 & 11.96 & 27.34 & 33.12 \\
\hline $\mathrm{CV}(\%)$ & 1.09 & 4.66 & 9.82 & 3.43 & 10.43 & 6.35 & 9.61 & 3.71 \\
\hline $\mathrm{H}^{2}$ & 97.85 & 89.6 & 86.94 & 54.41 & 92.22 & 86.22 & 89.82 & 69.84 \\
\hline
\end{tabular}

${ }^{1}$ Means followed by the same letter in each column belong to the same group according to the grouping criteria of Scott-Knott at $5 \%$ probability;

${ }^{2 /}$ WC: Water Content; ${ }^{3 /}$ GR: Germination Rate; ${ }^{4 /}$ RRL: Relative Radicle Length (ISTA); ${ }^{5 /}$ ARL: Average Radicle Length (AOSA); ${ }^{6 /}$ RHL: Relative Hypocotyl Length (ISTA); ${ }^{7 /}$ AHL: Average Hypocotyl Length (AOSA); ${ }^{8 /}$ RLS: Relative Length of Seedlings (ISTA); ${ }^{9 /}$ ALS: Average Length of Seedling (AOSA). 
According to Vanzolini and Carvalho (2002), root length and dry matter accumulation are efficient features to classify the vigor of soybean seeds. Schuab et al. (2002) found a positive correlation between the growth of plants and various tests for the estimation of soybean seeds vigor, confirming the analysis efficiency of the length as a means of verification of the physiologic quality. According to Vanzolini et al. (2007), obtaining average lengths of seedlings according to the methodology recommended by ISTA enables the detection of subtle differences between genotypes for seed quality. This is consistent, as the method takes into account the number of normal seedlings in relation to the number of seeds placed in the test.

For such protocol, cultivars CD206, CD211, CD217, UFV19, Msoy8605 and Confiança should be noted, with the highest average length of radicle, hypocotyl and seedling. The CD 202 genotype, with the lowest germination rate (Table 1), was also discriminated from the others on the relative length of radicle (RRL) and seedling (RLS), a relationship of development of seedling - physiological quality already announced by Vanzolini et al. (2007) and Dias et al. (2011).

On the other hand, following the recommendation of AOSA, the identification of the potential of genotypes with a lower rate of germination was favored. Also considering the CD202 genotype as a model, the average lengths of their radicles and seedlings (ARL and ALS) were similar to those of other genotypes that did well in other tests, thus showing good potential (Table 1). This information is useful if a strain in an enhancement program has the potential for initial development, but other factors, such as germination rate, are negatively interfering.

This makes it possible to reflect if the cause of the interruption in germination could be bypassed, and the strain is more carefully assessed. Both calculation recommendations of the average length of an experimental plot (ISTA and AOSA) generate important information and views about the same genotype (Vanzolini et al., 2007).

In terms of biomass, the existence of variability among genotypes for dry matter weight stands out, which was also noticed by Maia et al. (2011) in beans. Genotypes Emgopa315 and UFV19 were the ones that most accumulated dry matter in seedlings in the experimental plot (SDMW) and continued among the top ones after the correction for 50 seedlings (EDMW). The dry matter accumulation in the early stages of the cycle is very important for the crop, especially in seedling emergence, which can be difficult because of the depth of seeding and/or soil crusting. Costa et al. (1999) have stated that seedling emergence depends on the development of the hypocotyl, responsible for the rise of the cotyledons above the surface. Thus, hypocotyl length and diameter are related to the ability of seedling emergence and overcoming any resistance of the ground. Pereira et al. (2009) have simulated this situation in testing seedlings height, and have noticed that when the seedlings find resistance to their growth, they respond with the thickening of the hypocotyl and reduction in size, which in practice means increased strength to overcome the barrier imposed on them.

In terms of mobilization of reserves, two genotypes, CD217 and CD211, were grouped as superior to others for characteristic CESR (Table 2). These genotypes were among the ones that least mobilized reserves (RRS and SRRR); however, proportionally they were the most efficient in converting what they mobilized of reserves into seedlings dry matter. Whereas these were not the genotypes containing more reserves in their remaining cotyledons, their efficiency can be a character to be relieved in the assessment of strains. Soltani et al. (2006) have highlighted that seeds different in size may differ in RRS and CESR. In practice, the dry matter of the seedling originated from a large seed, but with little mobilization of reserves, is equal to that of a seedling from a small seed with high reserve mobilization.

Analyzing the correlations among the characteristics (Table 3), the average length of radicle, hypocotyl, seedling and dry matter yield (RRL, RHL, RLS, RYDM) are positively correlated with the germination rate (GR) of the experimental plot, and are also related to the dry matter accumulation in the experimental plot. These correlations are explained by the fact that the relative values of the lengths and yield of dry matter yield would be greater the more seeds germinated. However, the positive correlation between germination rate (GR) and average length of hypocotyl (AHL) indicated that plots with higher germination rates tend to have higher average length of the hypocotyl. According to this observation, a correlation between the average length of hypocotyl (AHL) and the relative length of seedling, relative dry matter of seedling and relative yield of dry matter (RLS, SDMW, RYDM) was found. According to Pereira et al. (2013), hypocotyl is more sensitive than the radicle under water stress; therefore it is important to observe its development, as it is more sensitive to changes caused by the environment. However, the correlation between the relative lengths of hypocotyl, radicle and seedling points to the plausible fact of maintaining the proportions in the measurements of seedlings in different cultivars. 
Table 2. Means of 16 characteristics of 14 soybean genotypes and formation of groups by the Scott-Knott criterion.

\begin{tabular}{|c|c|c|c|c|c|c|c|c|}
\hline \multirow{3}{*}{ Cultivars } & \multicolumn{8}{|c|}{ Assessed characteristics ${ }^{/ 1}$} \\
\hline & $\mathrm{SDMW}^{/ 2}$ & $\mathrm{EDMW}^{/ 3}$ & $\mathrm{DWS}^{/ 4}$ & $\mathrm{RDWC}^{/ 5}$ & $\mathrm{RRS}^{/ 6}$ & $\mathrm{CESR}^{/ 7}$ & $\mathrm{RYDM}^{/ 8}$ & $\mathrm{SRRR}^{/ 9}$ \\
\hline & g & g & g & $\mathrm{g}$ & $\mathrm{g}$ & $\%$ & g & $\%$ \\
\hline CD217 & $.77 \mathrm{~b}$ & $2.07 \mathrm{c}$ & 5.591 & $2.95 \mathrm{~b}$ & $2.64 \mathrm{e}$ & $79.3 \mathrm{a}$ & $.038 \mathrm{~b}$ & $47.3 \mathrm{~d}$ \\
\hline $\mathrm{CD} 211$ & $.61 \mathrm{c}$ & $1.87 \mathrm{~d}$ & $5.22 \mathrm{~m}$ & $2.72 \mathrm{c}$ & $2.49 \mathrm{e}$ & $74.8 \mathrm{a}$ & $.031 \mathrm{c}$ & $47.9 \mathrm{~d}$ \\
\hline CD219 & $.61 \mathrm{c}$ & $1.83 \mathrm{~d}$ & $5.70 \mathrm{k}$ & $2.73 \mathrm{c}$ & $2.97 \mathrm{~d}$ & $62.8 \mathrm{~b}$ & $.030 \mathrm{c}$ & $52.1 \mathrm{c}$ \\
\hline Emgopa315 & $.96 \mathrm{a}$ & $2.60 \mathrm{a}$ & $6.84 \mathrm{e}$ & $3.06 \mathrm{~b}$ & $3.79 \mathrm{~b}$ & $68.8 \mathrm{~b}$ & $.048 \mathrm{a}$ & $55.3 \mathrm{~b}$ \\
\hline UFV19 & $.91 \mathrm{a}$ & $2.55 \mathrm{a}$ & $7.38 \mathrm{a}$ & $3.25 \mathrm{a}$ & $4.12 \mathrm{a}$ & $62.0 \mathrm{~b}$ & $.045 \mathrm{a}$ & $55.9 \mathrm{~b}$ \\
\hline CD202 & $.45 \mathrm{~d}$ & $2.22 \mathrm{~b}$ & $6.40 \mathrm{~g}$ & $2.91 \mathrm{~b}$ & $3.48 \mathrm{c}$ & $63.7 \mathrm{~b}$ & $.023 \mathrm{~d}$ & $54.4 \mathrm{~b}$ \\
\hline UFVTN103 & $.54 \mathrm{~d}$ & $1.62 \mathrm{e}$ & $4.53 n$ & $1.85 \mathrm{e}$ & $2.68 \mathrm{e}$ & $61.1 \mathrm{~b}$ & $.027 \mathrm{~d}$ & $59.1 \mathrm{a}$ \\
\hline UFV18 & $.79 \mathrm{~b}$ & $2.50 \mathrm{a}$ & $6.97 \mathrm{c}$ & $3.30 \mathrm{a}$ & $3.68 \mathrm{~b}$ & $68.3 \mathrm{~b}$ & $.039 \mathrm{~b}$ & $52.7 \mathrm{c}$ \\
\hline UFV16 & $.65 \mathrm{c}$ & $2.32 \mathrm{~b}$ & $6.30 \mathrm{~h}$ & $2.89 \mathrm{~b}$ & $3.41 \mathrm{c}$ & $68.0 \mathrm{~b}$ & $.032 \mathrm{c}$ & $54.1 \mathrm{~b}$ \\
\hline MSOY8605 & $.84 \mathrm{~b}$ & $2.32 \mathrm{~b}$ & $6.58 \mathrm{f}$ & $2.93 \mathrm{~b}$ & $3.65 \mathrm{~b}$ & $65.0 \mathrm{~b}$ & $.042 \mathrm{~b}$ & $55.5 \mathrm{~b}$ \\
\hline Monarka & $.67 \mathrm{c}$ & $2.12 \mathrm{c}$ & $5.74 \mathrm{i}$ & $2.33 \mathrm{~d}$ & $3.41 \mathrm{c}$ & $62.6 \mathrm{~b}$ & $.033 \mathrm{c}$ & $59.3 \mathrm{a}$ \\
\hline Confiança & $.82 \mathrm{~b}$ & $2.32 \mathrm{~b}$ & $6.90 \mathrm{~d}$ & $3.19 \mathrm{a}$ & $3.70 \mathrm{~b}$ & $62.9 \mathrm{~b}$ & $.041 \mathrm{~b}$ & $53.7 \mathrm{~b}$ \\
\hline UFVTN105 & $.79 \mathrm{~b}$ & $2.44 \mathrm{a}$ & $7.05 \mathrm{~b}$ & $3.34 \mathrm{a}$ & $3.71 \mathrm{~b}$ & $65.6 \mathrm{~b}$ & $.039 \mathrm{~b}$ & $52.7 \mathrm{c}$ \\
\hline CD 206 & $.78 \mathrm{~b}$ & $2.13 \mathrm{c}$ & $5.72 \mathrm{j}$ & $2.32 \mathrm{~d}$ & $3.40 \mathrm{c}$ & $62.8 \mathrm{~b}$ & $.038 \mathrm{~b}$ & $59.4 \mathrm{a}$ \\
\hline Mean & 0.73 & 2.21 & 6.21 & 2.84 & 3.37 & 66.3 & 0.04 & 54.3 \\
\hline $\mathrm{CV}(\%)$ & 10.37 & 7.03 & 0.05 & 5.44 & 4.59 & 11.0 & 9.12 & 2.43 \\
\hline $\mathrm{H}^{2}$ & 93.09 & 92.81 & 99.99 & 96.71 & 97.48 & 52.80 & 94.64 & 87.76 \\
\hline
\end{tabular}

${ }^{1 /}$ Means followed by the same letter in each column belong to the same group according to the grouping criteria of Scott-Knott at $5 \%$ probability;

${ }^{2}$ SDMW: Seedlings Dry Matter Weight (ISTA);

${ }^{3 /}$ EDMW: Estimated Dry Matter Weight for 50 seedlings;

${ }^{4 /}$ DWS: Dry Weight of Seeds;

${ }^{5 /}$ RDWC: Remaining Dry Weight of the Cotyledons;

${ }^{6 /}$ RRS: Reduction of Reserves of Seeds;

" CESR: Conversion Efficiency of Seeds Reserve;

${ }^{8 /}$ RYDM: Relative Yield of Dry Matter;

9/ SRRR: Seed Reserve Reduction Rate.

The dry matter of seeds (DWS) is positively correlated with the reduction of reserves of seeds (RRS), which is consistent because seeds with more dry matter have more reserves to be mobilized. Soltani et al. (2006) have also witnessed such fact. Importantly, the DWS and RRS characteristics are positively correlated with the dry matter weight of seedlings (SDMW and EDMW), which may indicate that seeds with more reserves result in seedlings with higher dry matter accumulation. In fact, what is confirmed in the analysis of means of genotype UFV19. Pádua et al. (2010) and Pereira et al. (2013) has related the larger size of the seeds with the best seedling development, indicating superiority of large seeds in the formation of the stand (Table 3). These findings make sense in the observation that the reduction in reserves of seeds (RRS) correlates with the relative yields of dry matter (RYDM).

Based on these findings, selecting seeds with more reserves in genetic enhancement can be an interesting strategy, because even if the gains will disappear during the plant cycle
(Camozzato et al., 2009), seeds with more reserves may result in an initial stronger development (Pádua et al., 2010), favoring fast soil coverage (Soltani et al., 2006).

Another important finding of this study was the negative correlation between the seed reserve reduction rate (SRRR) and the conversion efficiency of reserves (CESR). This proves that the reduction of reserves of the seeds does not mean, in direct relation, its conversion into dry matter of seedlings. It is plausible to assume an increased respiratory rate in larger seeds, since practically the whole soybean seed tissue is formed by living cells. Whereas seedlings with strong hypocotyls are more adept at breaking the soil surface (Costa et al., 1999), an interesting situation in the assessment of new strains would be the search for strains able to present a positive correlation between RRS and CESR characteristics, as it would combine a considerable stock of reserves associated with an efficient conversion system in seedling dry matter. Soltani et al. (2006) have shown a priori that these characteristics are under genetic control. 
68

W. A. PEREIRA et al.

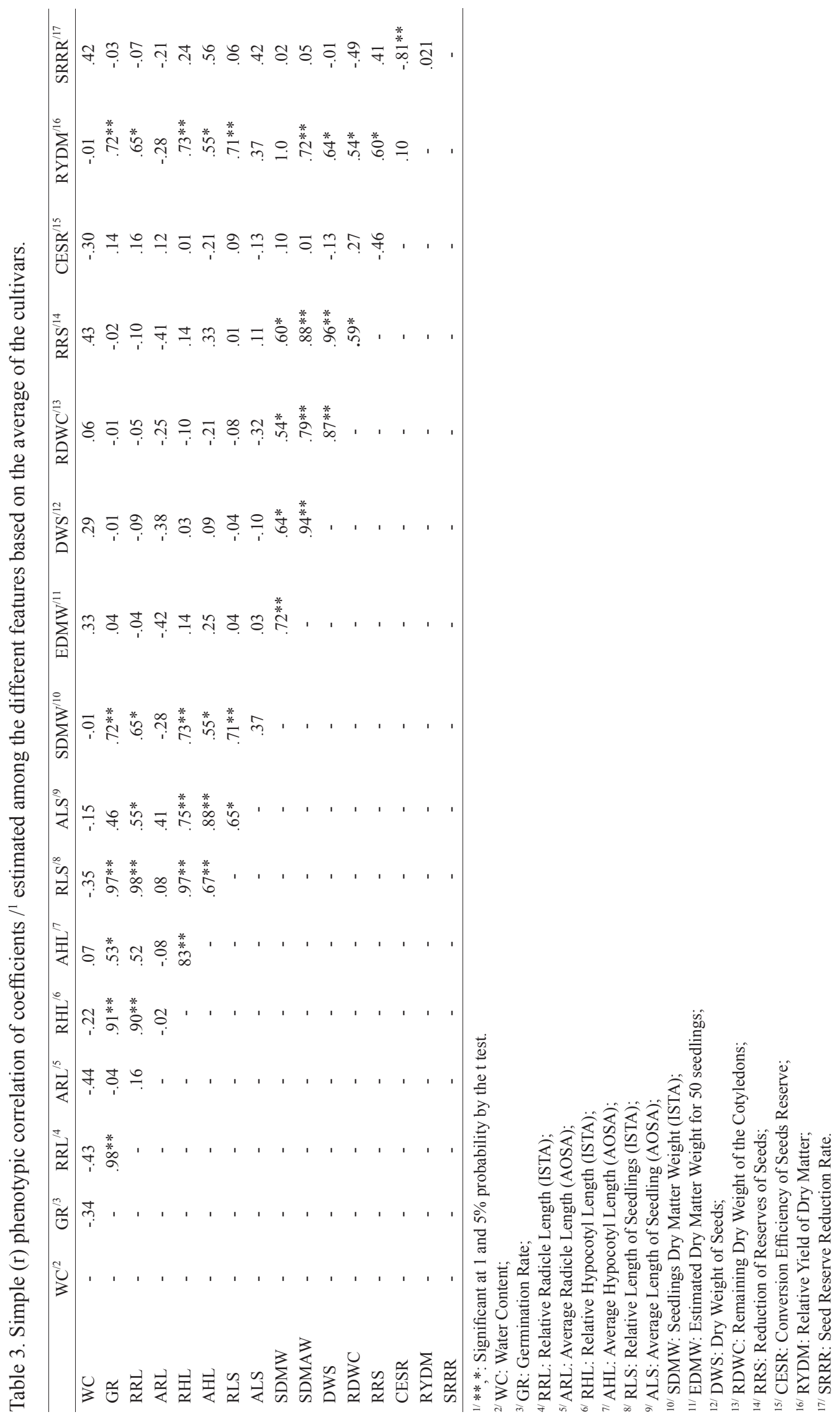

Journal of Seed Science, v.37, n.1, p.063-069, 2015 


\section{Conclusions}

Dry matter weight of seeds, reduction of seeds reserve and dry matter weight of seedlings are positively correlated, and thus genotypes whose seeds are large have a potential vigor on the initial development of seedlings.

Seeds reserve reduction and conversion efficiency of seeds reserves are negatively correlated.

\section{Acknowledgments}

To Conselho Nacional de Desenvolvimento Científico e Tecnológico (CNPq - National Counsel of Technological and Scientific Development) and Fundação de Amparo à Pesquisa e Inovação do Espírito Santo (FAPES - Research Support Foundation of the Brazilian State of Espírito Santo) by granting scholarships to the authors of this research.

\section{References}

AOSA. ASSOCIATION OF OFFICIAL SEED ANALYSTS. Seed vigor testing handbook, 2009. 341p.

BRASIL. Ministério da Agricultura, Pecuária e Abastecimento. Regras para análise de sementes. Ministério da Agricultura, Pecuária e Abastecimento. Secretaria de Defesa Agropecuária. Brasília, DF: MAPA/ACS, 2009. 395p. http:// www.agricultura.gov.br/arq_editor/file/2946_regras_analise_sementes.pdf.

CÂMARA, G.M.S.; PIEDADE, S.M.S.; MONTEIRO, J.H.; GUERZONI, R.A. Desempenho vegetativo e produtivo de cultivares e linhagens de soja de ciclo precoce no município de Piracicaba - SP. Scientia Agrícola, v.55, n.3, p.403-412, 1998. http://www.scielo.br/scielo.php?pid=S0103$90161998000300008 \&$ script $=$ sci_arttext

CAMOZZATO, V.A.; PESKE, S.T.; POSSENTI, J.C.; MENDES, A.S. Desempenho de cultivares de soja em função do tamanho das sementes. Revista Brasileira de Sementes, v.31, n.1, p.288-292, 2009. http://www. scielo.br/pdf/rbs/v31n1/a32v31n1.pdf

CARVALHO, J.A.; SOARES, A.A.; REIS, M.S. Efeito de espaçamento e densidade de semeadura sobre a produtividade e os componentes de produção da cultivar de arroz BRSMG Conai. Ciência e Agrotecnologia, v.32, n.3, p.785-791, 2008. http://www.scielo.br/pdf/cagro/v32n3/a12v32n3.pdf

COSTA, J.A.; PIRES, J.L.F.; THOMAS, A.L.; ALBERTON, M. Comprimento e índice de expansão radial do hipocótilo de cultivares de soja. Ciência Rural, v.29, n.4, p.609-612, 1999. http://www.scielo.br/pdf/cr/v29n4/a06v29n4.pdf

DIAS, M.A.N.; PINTO, T.L.F.; MONDO, V.H.V.; CICERO, S.M.; PEDRINI, L.G. Direct effects of soybean seed vigor on weed competition. Revista Brasileira de Sementes, v.33, n.2, p.346-351, 2011. http://www.scielo.br/pdf/ rbs/v33n2/17.pdf

HENNING, F.A.; MERTZ, L.M.; JACOB JUNIOR, E.A.; MACHADO, R.D.; FISS, G.; ZIMMER, P.D. Composição química e mobilização de reservas em sementes de soja de alto e baixo vigor. Bragantia, v.69, n.3, p.727-734, 2010. http://www.scielo.br/pdf/brag/v69n3/26.pdf
MAIA, L.G.; SILVA, C.A.; RAMALHO, M.A.P.; ABREU, A.F. Variabilidade genética associada à germinação e vigor de sementes de linhagens de feijoeiro comum. Ciência e Agrotecnologia, v.35, n.2, p.361-367, 2011. http://www. scielo.br/pdf/cagro/v35n2/a18v35n2.pdf

NEPOMUCENO, M.; ALVES, P.L.C.A.; DIAS, T.C.S.; PAVANI, M.C.M.D Períodos de interferência das plantas daninhas na cultura da soja nos sistemas de semeadura direta e convencional. Planta Daninha, v.25, n.1, p.43-50, 2007. http://www.scielo.br/pdf/pd/v25n1/a05v25n1.pdf

PÁDUA, G.P.; ZITO, R.K.; ARANTES, N.E.; FRANÇA-NETO, J.B Influência do tamanho da semente na qualidade fisiológica e na produtividade da cultura da soja. Revista Brasileira de Sementes, v.32, n.3, p.9-16, 2010. http://www.scielo.br/pdf/rbs/v32n3/v32n3a01.pdf

PEREIRA, W.A.; SÁVIO, F.L.; BORÉM, A.; DIAS, D.C.F.S. Influência da disposição, número e tamanho das sementes no teste de comprimento de plântulas de soja. Revista Brasileira de Sementes, v.31, n.1, p.113-121, 2009. http://www.scielo.br/pdf/rbs/v31n1/a13v31n1.pdf

PEREIRA, W.A.; PEREIRA, S.M.A.; DIAS, D.C.F.S. Influence of seed size and water restriction on germination of soybean seeds and on early development of seedlings. Journal of Seed Science, v.35, n.3, p.316-322, 2013. http://www.scielo.br/pdf/jss/v35n3/07.pdf

SCHUAB, S.R.P.; BRACCINI, A.L.; FRANÇA-NETO, J.B.; SCAPIM, C.A.; MESCHEDE, D.K. Utilização da taxa de crescimento das plântulas na avaliação do vigor de sementes de soja. Revista Brasileira de Sementes, v.24, n.2, p.90-95, 2002. http://www.scielo.br/pdf/rbs/v24n2/v24n2a15.pdf

SOLTANI, A.; GALESHI, S.; ZEINALI, E.; LATIFI, N. Germination, seed reserve utilization and seedling growth of chickpea as affected by salinity and seed size. Seed Science and Technology, v.30, p.51-60, 2002.

SOLTANI, A.; GHOLIPOOR, M.; ZEINALI, E. Seed reserve utilization and seedling growth of wheat as affected by drought and salinity. Environmental and Experimental Botany, v.55, n.1-2, p.195-200, 2006. http://www. sciencedirect.com/science/article/pii/S0098847204001534\#

SUN, Q; WANG, J.H; SUN, B.Q. Advances on seed vigor physiological and genetic mechanisms. Agricultural Sciences in China, v.6, p.1060-1066, 2007. http://www.sciencedirect.com/science/article/pii/S1671292707601473\#

VALÉRIO, I.P.; CARVALHO, F.I.F.; OLIVEIRA, A.C.; BENIN, G.; SOUZA, V.Q.; MACHADO, A.A.; BERTAN, I.; BUSATO, C.C; SILVEIRA, G.; FONSECA, D.A.R. Seeding density in wheat genotypes as a function of tillering potential. Scientia Agricola, v.66, n.1, p.28-39, 2009. http://www scielo.br/pdf/sa/v66n1/a04v66n1.pdf

VANZOLINI, S.; ARAKI, C.A.S.; SILVA, A.C.T.M.; NAKAGAWA, J. Teste de comprimento de plântulas na avaliação da qualidade fisiológica de sementes de soja. Revista Brasileira de Sementes, v.29, n.2, p.90-96, 2007. http://www.scielo.br/pdf/rbs/v29n2/v29n2a12.pdf

VANZOLINI, S.; CARVALHO, N.M. Efeito do vigor de sementes de soja sobre o seu desempenho em campo. Revista Brasileira de Sementes, v.24, n.1, p.33-41, 2002. http://www.scielo.br/pdf/rbs/v24n1/v24n1a06.pdf 